\title{
Advances in Superplasticity
}

by

\author{
Kenji Higashi*
}

\section{1 はじめに}

微細粒超塑性は, 材料を応力のひずみ速度感受性指 数 $\mathrm{m}$ 值の大きい条件に保持しながら変形すると, 非 常に低い流動応力と大きな伸び值を示す現象を言う. 超塑性の歴史は古く, その現象のルーツは今世紀初頭 までさかのぼる. Pearson のぐるぐる巻きの $2000 \%$ 伸び值の写真（Bi-43Sn 共晶合金）は, 超塑性に対 する強い関心を集めた。第二次世界大戦後, Underwood の解説を機に活発な研究が再開されたが, 超塑 性の明確な解析を為すまでには至らなかった。この超 塑性の混沌期に終止符を打ったのは，Backofen であ る. 彼の業績は有名な超塑性流動応力とひずみ速度の 現象論的基礎式に集約される. 彼の一連の業績は, 超 塑性研究の基礎的指針であり, 現在でも超塑性変形機 構を考察する上で中心的役割を果たしている.

1970 年代以降は, 超塑性の黎明期で, 新しい超塑 性ニッケル基，チタン基，アルミニウム基そして鉄基 合金などが次々と開発，実用化された。年かがて超塑性 を利用した真空あるいはブロー成形品等が工業的に製 造され始めると, 超塑性成形後の機械的諸特性が意識 されるようになった，当時の結晶粒微細化による材料 の高強度, 高じん性指向の気運とも重なって, 既存の 実用合金に超塑性特性を付与する加工熱処理法の研究 が活発化した．最近では，急冷凝固技術の発展と粉末 治金技術の応用により，高含有率の複相合金あるいは 複合材料, メカニカル合金, ‘ラミッックスなどでも超 塑性的挙動が見い出されている. こうした超塑性の世 界的規模での高まりは，ここ数年間の超塑性に関連し た国際会議開催の頻繁さからもうなづける。各会議 の主テーマや発表論文のタイトルを眺めると,〈超塑 性の一般的特徽〉 $\rightarrow$ 〈超塑性機構と超塑性の問題点〉 $\rightarrow 〈$ 超塑性の利用と応用〉と言った歴史的流れを読み
取ることが出来る．既に，現在は超塑性の円熟期ある いは終焉期?に突入した感がある.

超塑性は約半世紀以上の長い年月にわたって進化し てきたが，この間，超塑性ミクロ組織に対する認識も また徐々に変化してきた，特に，ここ数年における超 塑性ミク口組織に対する認識の変化は非常に大きい. この変化は, 超塑性に関する研究の充実さもさること ながら，最近の急冷凝固や粉末治金技術の発展，ある いは工場の熱間加工を含めた製造設備の充実に起因し た実用合金の加工熱処理法の顕著な発達に因るところ 大であると筆者は考えている，本小文では，超塑性の 歩んで来た歴史的背景を踏まえ, 各時代の超塑性研究 の推移より遊離してきた問題点を指摘し，筆者なりに それらを総括，概説する．また蛇足ながら，本題目の 〈超塑性の前進〉は, 超塑性の終焉を切に希望する著 者の気持ちを込めたものである.

\section{2 超塑性材料の歴史}

超塑性ミクロ組織に対する認識の変化を指摘する前 に大ざっぱな超塑性材料の歴史を眺めてみよう，表 I は，代表的な超塑性材料を年代順に整理したものであ る. 合金組成，超塑性発現条件（温度とひずみ速度）, 超塑性能力の目安となる $\mathrm{m}$ 值, 最大破断伸び值, 合 金の初期ミクロ組織および超塑性変形中の組織変化の 有無等を記入している. 超塑性ミクロ組織の多くが超 塑性状態ではミクロンオーダーの微細均一組織であり, また超塑性変形中の組織変化がひずみ誘起粒成長以外 には無く,ミクロ組織の大きな変動が超塑性変形中見 られないこどなどが一般的特徵になっている.

こうした多くの超塑性材料の代表的なミクロ組織の

*1 厳密には, ひずみ誘起粒成長自身, 変形中に生じる合金のミクロ 組織変化である. しかし, 従来より, 超塑性変形中の粒成長は超 塑性の一般的特徵とされてきた.ここでは, 後述する変形間中の 大きなミクロ組織の変動と区別して用いる.

$\dagger$ 原稿受理 昭和63年12月 8 日 $\quad$ Received Dec. 8, 1988

* 正会員 大阪府立大学工学部 堺市百舌鳥梅町, Department of Metallurgical Engineering, University of Osaka Prefecture, Mozu-Umemachi, Sakai 
類推から，一般的な超塑性ミクロ組織は次のように分 類する事が出来る.

（1）ミクロンオーダーの微細均一等量組織を有する 共晶, 共析合金

（2）共晶，共析合金以外の二相等量あるいは二相混 合組織から成る微細均一複相合金

(3) 微細均一再結晶粒組織から成る単相合金

現在までに発表された超塑性関連記事は約 2000 件 にも及ぶ. 図 1 は, 超塑性に関連した報告例を, 超塑 性ミクロ組織の代表的な種類別に区別して各年代ごと に示したものである. 1960 年代の発表件数のほとん どは複相合金に関するものである．その後，発表件数 は顕著に増加しているが，各時代とも共晶，共析合金 のような二相等量組織が超塑性材料の代表例として君 臨している．しかし，共晶，共析合金以外の二相等量 あるいは二相混合組織から成る複相合金も増加してい る. 時代とともに, 微細再結晶粒組織から成る単相合 金が，超塑性材料として取り扱われる頻度が多くなっ ている.この傾向は, 加工熱処理法の発展に伴う既存

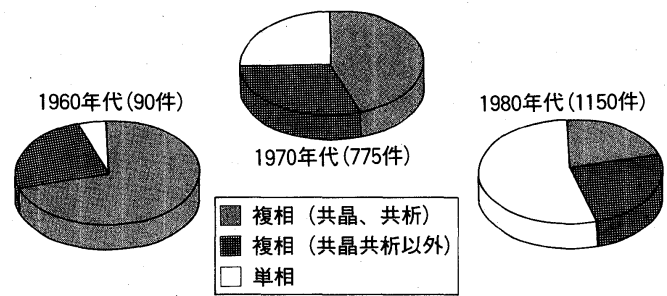

図 1 代表的な超塑性ミクロ組織の種類別の歴史的 推移

実用合金の超塑性化の開発経緯に対応している.

これら超塑性ミクロ組織の共通した特徵はミクロン オーダーの均一微細再結晶粒組織である. 歴史的に見 て複相合金が主流であったのは，複相合金が単相合金 より均一微細な超塑性ミク口組織を得ることが容易で, なおかつ高温変形中でも安定な微細組織を保持できる ためである。これらは異相界面の高温での移動速度が 同相界面のそれより小さいことに起因する，また，複

*2 厳密な意味での単相合金ではない.ここでは, 第二相粒子体積率 が $10 \%$ 以下の合金と言う意味で用いる.

表 I 超塑性材料の歴史

\begin{tabular}{|c|c|c|c|c|c|c|c|}
\hline 年 代 & 合金の組成 (wt\%) & 温度 $\left({ }^{\circ} \mathrm{C}\right)$ & ひずみ速度 (/s) & $\mathrm{m}$ 値 & $\begin{array}{c}\text { 最大伸び値 } \\
(\%)\end{array}$ & 合金のミクロ組織 & $\begin{array}{l}\text { 組織変化 } \\
\text { の 有 }\end{array}$ \\
\hline 1912 & $\mathrm{Cu}-40 \mathrm{Zn}$ & - & - & - & 200 & $\alpha+\beta$ 共晶 & - \\
\hline 1920 & $\mathrm{Zn}-10 \mathrm{Al}-10 \mathrm{Cu}$ & - & - & - & - & 共晶 & 一 \\
\hline 1928 & $\mathrm{Cd}-27 \mathrm{Zn}$ & $20 \sim 30$ & - & 0.5 & 350 & - & - \\
\hline 1934 & $\mathrm{Bi}-43 \mathrm{Sn}$ & $20 \sim 30$ & - & - & 1950 & 共晶 & - \\
\hline 1964 & $\mathrm{Zn}-20 \mathrm{Al}$ & 250 & $5 \times 10^{-4} \sim 5 \times 10^{-3}$ & $\sim 0.5$ & 1000 & 共析 & - \\
\hline 1965 & $\mathrm{Sn}-38 \mathrm{~Pb}$ & 20 & $10^{-4} \sim 10^{-2}$ & 0.5 & 1584 & 共晶 $(1 \sim 3 \mu)$ & - \\
\hline 1966 & $\mathrm{Al}-33 \mathrm{Cu}$ & $360 \sim 520$ & $10^{-4} \sim 10^{-2}$ & 0.7 & $>500$ & 共晶 $(2 \sim 8 \mu)$ & 無 \\
\hline \multirow[t]{5}{*}{1967} & $\mathrm{Co}-10 \mathrm{Al}$ & 1200 & - & 0.5 & 850 & 共晶 & - \\
\hline & $\mathrm{Ni}-39 \mathrm{Cr}-10 \mathrm{Fe}-2 \mathrm{Ti}-1 \mathrm{Al}$ & $810-980$ & $10^{-4} \sim 10^{-2}$ & 0.5 & 1000 & 二相混合 $(3 \sim 7 \mu)$ & 無 \\
\hline & $\mathrm{Sn}-5 \mathrm{Bi}$ & 20 & $10^{-3} \sim 10^{-2}$ & 0.7 & $>1000$ & 微細再結晶粒 $(1 \sim 5 \mu)$ & 無 \\
\hline & $\mathrm{Sn}-38 \mathrm{~Pb}$ & $0 \sim 80$ & $10^{-4} \sim 10^{-2}$ & 0.5 & 1500 & 共晶 & 無 \\
\hline & $\mathrm{Ti}-6 \mathrm{Al}-4 \mathrm{~V}$ & $800 \sim 1000$ & $10^{-5} \sim 10^{-3}$ & 0.9 & 1000 & $\alpha+\beta$ 共晶 $(7 \sim 20 \mu)$ & 無 \\
\hline \multirow[t]{3}{*}{1968} & $\mathrm{Fe}^{-0.1} \sim 0.5 \mathrm{C}$ & $700 \sim 1000$ & $10^{-5} \sim 10^{-3}$ & $0.3 \sim 0.7$ & 450 & $\alpha(<10 \mu)+$ 微細分散 $\mathrm{Fe}_{3} \mathrm{C}$ & - \\
\hline & $\mathrm{Mg}-6 \mathrm{Zn}-0.5 \mathrm{Zr}$ & $270 \sim 310$ & $10^{-3} \sim 10^{-2}$ & 0.5 & $>1000$ & $\alpha(1 \sim 5 \mu)+$ 微細分散粒子 & 無 \\
\hline & $\mathrm{Ni}-35 \mathrm{Cr}-26 \mathrm{Fe}-0.6 \mathrm{Ti}$ & $795 \sim 855$ & $10^{-3} \sim 10^{-2}$ & 0.5 & $>1000$ & 二相結合 & 無 \\
\hline 1969 & $\mathrm{Mg}-34 \mathrm{Al}$ & $250 \sim 400$ & $10^{-5}-10^{-2}$ & 0.8 & 2100 & $\delta+\gamma$ 共晶 $(2 \mu)$ & 無 \\
\hline 1970 & $\mathrm{Zn}-22 \mathrm{Al}$ & $200 \sim 300$ & $10^{-4} \sim 10^{-2}$ & $0.5 \sim 0.6$ & 1500 & 共 析 & 無 \\
\hline \multirow[t]{2}{*}{1971} & $\mathrm{Cu}-10 \mathrm{Al}-4 \mathrm{Fe}$ & 800 & $10^{-4} \sim 10^{-3}$ & 0.5 & $\sim 800$ & 共晶 $(5 \mu)$ & 無 \\
\hline & $\mathrm{Cu}-3 \mathrm{Al}-2 \mathrm{Si}-0.4 \mathrm{Co}$ & $500 \sim 600$ & $10^{-5} \sim 10^{-3}$ & 0.5 & $\sim 300$ & 微細再結晶粒 $(\sim 10 \mu)$ & 無 \\
\hline 1972 & $\mathrm{Cu}-10 \mathrm{Al}$ & $540 \sim 700$ & $10^{-4} \sim 10^{-2}$ & 0.7 & 700 & 共晶 & 無 \\
\hline$*$ & $\mathrm{Cu}-7 \mathrm{P}$ & $410 \sim 600$ & $10^{-4} \sim 10^{-2}$ & 0.5 & $>600$ & $\alpha+\beta$ 共晶 $(\sim 10 \mu)$ & 有 \\
\hline$*$ & $\mathrm{Ti}-8 \mathrm{Mn}$ & $750 \sim 900$ & $10^{-5} \sim 10^{-2}$ & $\sim 1.0$ & 150 & $\beta$ 単相 $(500 \mu)$ & 有 \\
\hline$*$ & $\mathrm{Ti}-15 \mathrm{Mo}$ & $820 \sim 920$ & $10^{-5} \sim 10^{-2}$ & $\sim 1.0$ & 450 & $\beta$ 単相 $(300 \mu)$ & 有 \\
\hline \multirow[t]{2}{*}{1973} & $\mathrm{Al}-11 \mathrm{Zn}-1 \mathrm{Mg}-0.4 \mathrm{Zr}$ & 550 & $10^{-4} \sim 10^{-3}$ & 0.9 & 1550 & 微細再結晶粒 $(7 \mu)$ & 無 \\
\hline & $\mathrm{Zn}-22 \mathrm{Al}$ & $20 \sim 250$ & $10^{-3} \sim 10^{-2}$ & 0.5 & 2500 & 共析 $(\sim 2 \mu)$ & 無 \\
\hline \multirow[t]{2}{*}{1974} & $\mathrm{Fe}-26 \mathrm{Cr}-7 \mathrm{Ni}$ & $700 \sim 1020$ & $10^{-5} \sim 10^{-2}$ & 0.6 & 600 & 二相混合 $(5 \mu)$ & 無 \\
\hline & $\mathrm{Fe}-0.03 \sim 0.1 \mathrm{C}$ & $850 \sim 1000$ & - & 0.7 & 820 & 二相混合 & 無 \\
\hline 1975 & $\mathrm{Al}-25 \mathrm{Cu}-5 \mathrm{Si}$ & 500 & $10^{-3}$ & 0.4 & 1306 & 共晶 $(\sim 2 \mu)$ & 無 \\
\hline \multirow[t]{2}{*}{$*$} & $\mathrm{Al}-6 \mathrm{Cu}-0.5 \mathrm{Zr}$ & $400 \sim 500$ & $10^{-4} \sim 10^{-1}$ & 0.5 & 2000 & 亜結晶粒 $(<1 \mu)$ & 有 \\
\hline & $\mathrm{Fe}-1 \sim 2 \mathrm{C}$ & $650 \sim 900$ & $10^{-4} \sim 10^{-2}$ & $0.4 \sim 0.5$ & 500 & 二相混合 $\left(\alpha+\mathrm{Fe}_{3} \mathrm{C} / \alpha+\gamma\right)$ & 無 \\
\hline 1976 & $\mathrm{Al}-8 \mathrm{Ca}$ & $300 \sim 600$ & $10^{-4} \sim 10^{-2}$ & 0.8 & 850 & 共 晶 & 無 \\
\hline \multirow[t]{2}{*}{$*$} & $\mathrm{Al}-6 \mathrm{Cu}-0.5 \mathrm{Zr}$ & $350 \sim 475$ & $10^{-4} \sim 10^{-1}$ & 0.5 & $>1000$ & 亜結晶粒 $(<1 \mu)$ & 有 \\
\hline & $\mathrm{Al}-6 \mathrm{Mg}-0.4 \mathrm{Zr}-0.2 \mathrm{Mn}$ & $400 \sim 520$ & $10^{-4} \sim 10^{-3}$ & 0.6 & 890 & 微細再結晶粒 $(\sim 10 \mu)$ & 無 \\
\hline
\end{tabular}




\begin{tabular}{|c|c|c|c|c|c|c|c|}
\hline 年 代 & 合金の組成 (wt\%) & 温度 $\left({ }^{\circ} \mathrm{C}\right)$ & ひずみ速度 (/s) & $\mathrm{m}$ 值 & $\begin{array}{c}\text { 最大伸び值 } \\
(\%)\end{array}$ & 合金のミクロ組織 & $\begin{array}{l}\text { 組織変化 } \\
\text { の 有 無 }\end{array}$ \\
\hline 1977 & $\mathrm{Ti}-6 \mathrm{Al}-4 \mathrm{~V}$ & $815 \sim 927$ & $10^{-5} \sim 10^{-3}$ & 0.9 & $>100$ & $\alpha+\beta$ 共晶 $(\sim 8 \mu)$ & 無 \\
\hline$*$ & $\mathrm{Ti}-10 \mathrm{~V}-2 \mathrm{Fe}-3 \mathrm{Al}$ & $704 \sim 815$ & $10^{-7} \sim 10^{-3}$ & 0.7 & $>140$ & 擬 $\beta$ 単相 $(120 \mu)$ & 有 \\
\hline$*$ & Ti-15V-3Cr-3Sn-3Al & $704 \sim 815$ & $10^{-7} \sim 10^{-3}$ & 0.9 & $>140$ & $\beta$ 単相 $(55 \mu)$ & 有 \\
\hline \multirow[t]{2}{*}{1978} & $\mathrm{Cu}-38 \mathrm{Zn}-15 \mathrm{Ni}$ & 580 & $10^{-5} \sim 10^{-2}$ & 0.5 & 678 & $\alpha+\beta$ 共晶 & 無 \\
\hline & $\mathrm{Cu}-28 \mathrm{Zn}-15 \mathrm{Ni}-13 \mathrm{Mn}$ & 580 & $10^{-5} \sim 10^{-2}$ & 0.5 & 450 & $\alpha+\beta$ 共晶 & 無 \\
\hline 1979 & $\mathrm{Fe}-1.6 \sim 1.8 \mathrm{C}$ & 650 & $10^{-4}$ & 0.5 & 1680 & 二相混合 $\left(\alpha+\mathrm{Fe}_{3} \mathrm{C}\right)$ & 無 \\
\hline 1980 & $\mathrm{Al}-5 \mathrm{Ca}-5 \mathrm{Zn}$ & $450 \sim 550$ & $10^{-3} \sim 10^{-2}$ & 0.5 & 600 & 微細再結晶粒 $(<2 \mu)$ & 無 \\
\hline \multirow[t]{3}{*}{1981} & $\mathrm{Al}-6 \mathrm{Zn}-2 \mathrm{Mg}-2 \mathrm{Cu}-0.2 \mathrm{Cr}$ & $485 \sim 530$ & $10^{-4} \sim 10^{-3}$ & 0.7 & $>1000$ & 微細再結晶粒 $(\sim 10 \mu)$ & 無 \\
\hline & $\mathrm{Al}-3 \mathrm{Li}-0.5 \mathrm{Zr}$ & 450 & $10^{-3} \sim 10^{-2}$ & 0.5 & 1035 & 微細再結晶粒 $(\sim 2 \mu)$ & 無 \\
\hline & $\mathrm{Al}-4 \mathrm{Cu}-3 \mathrm{Li}-0.6 \mathrm{Zr}$ & 450 & $10^{-3} \sim 10^{-2}$ & 0.5 & 850 & 微細再結晶粒 $(\sim 2 \mu)$ & 無 \\
\hline 1982 & $\mathrm{Cu}-10 \mathrm{Al}-6 \mathrm{Ni}-5 \mathrm{Fe}-2 \mathrm{Mn}$ & $700 \sim 850$ & $10^{-3} \sim 10^{0}$ & 0.7 & $>5500$ & 二相混合 $(2 \mu)$ & 無 \\
\hline$*$ & $\mathrm{Fe}-25 \mathrm{Cr}-7 \mathrm{Ni}-3 \mathrm{Mo}$ & 950 & $10^{-3} \sim 10^{-1}$ & 0.5 & $>2500$ & 二相混合 $(\alpha+\gamma / \gamma+\sigma)$ & 有 \\
\hline 1983 & $\mathrm{Al}-6 \mathrm{Zn}-2 \mathrm{Cu}-2 \mathrm{Mg}-0.2 \mathrm{Cr}$ & 516 & $10^{-4}$ & 0.7 & $>1000$ & 微細再結晶粒 $(\sim 10 \mu)$ & 無 \\
\hline$*$ & $\mathrm{Al}-6 \mathrm{Cu}-0.5 \mathrm{Zr}$ & $400 \sim 530$ & $5 \times 10^{-3}$ & - & 1028 & 亜結晶粒 & 有 \\
\hline \multirow[t]{2}{*}{1984} & $\mathrm{Al}-5 \mathrm{Mg}-1 \mathrm{Cu}-1 \mathrm{Mn}-0.2 \mathrm{Cr}$ & $485 \sim 530$ & $10^{-4} \sim 10^{-3}$ & 0.7 & 800 & 微細再結晶粒 $(8 \sim 9 \mu)$ & 無 \\
\hline & $\mathrm{Al}-4 \mathrm{Cu}-2 \mathrm{Mg}-1 \mathrm{C}-0.8 \mathrm{O}$ & $400 \sim 500$ & $10^{-4} \sim 10^{+1}$ & 0.3 & 250 & - & - \\
\hline$*$ & Ti-15V-3Cr-3Sn-3Al & 815 & $10^{-4} \sim 10^{-3}$ & 0.5 & 230 & $\beta$ 単相 $(\sim 80 \mu)$ & 有 \\
\hline \multirow[t]{2}{*}{1985} & $\mathrm{Al}-6 \mathrm{Zn}-2 \mathrm{Mg}-2 \mathrm{Cu}-0.2 \mathrm{Zr}$ & 450 & $10^{-3} \sim 10^{-2}$ & 0.5 & 1000 & 微細再結晶粒 $(\sim 10 \mu)$ & 無 \\
\hline & $\mathrm{Al}-8 \mathrm{Zn}-3 \mathrm{Mg}-1 \mathrm{Cu}-1 \mathrm{Co}$ & 510 & $10^{-2}$ & $0.4 \sim 0.6$ & 500 & 亜結晶粒/一部再結晶 & 無 \\
\hline$*$ & $\mathrm{Al}-9 \mathrm{Zn}-1 \mathrm{Mg}-0.2 \mathrm{Zr}$ & 530 & $10^{-4} \sim 10^{-2}$ & 0.5 & 850 & 亜結晶粒 & 有 \\
\hline \multirow[t]{2}{*}{$*$} & $\mathrm{Cu}-40 \mathrm{Zn}-3 \mathrm{Al}-4 \mathrm{Mn}-1 \mathrm{~Pb}$ & $340 \sim 540$ & $10^{-4} \sim 10^{-3}$ & $\sim 0.4$ & 500 & $\beta$ 単相 $(\sim 200 \mu)$ & 有 \\
\hline & $\mathrm{ZrO}_{2}-3 \mathrm{molY}_{2} \mathrm{O}_{3}$ & $1150 \sim 1450$ & $10^{-4}$ & 0.5 & $\sim 200$ & 微細再結晶粒 $(\sim 0.3 \mu)$ & 無 \\
\hline 1986 & $\mathrm{Al}-6 \mathrm{Zn}-2 \mathrm{Mg}-2 \mathrm{Cu}-0.7 \mathrm{Zr}$ & 520 & $10^{-4}$ & - & 300 & 微細再結晶粒 $(\sim 6 \mu)$ & 無 \\
\hline$*$ & $\mathrm{Al}-6 \mathrm{Zn}-2 \mathrm{Mg}-2 \mathrm{Cu}-0.7 \mathrm{Zr}$ & 520 & $10^{-2} \sim 10^{-1}$ & - & $>500$ & 亜結晶粒 & 有 \\
\hline$*$ & $\mathrm{Al}-10 \mathrm{Mg}-0.5 \mathrm{Mn}$ & 300 & $10^{-4} \sim 10^{-2}$ & 0.5 & $\sim 600$ & 亜結晶粒 $(<0.5 \mu)$ & 有 \\
\hline \multirow[t]{2}{*}{1987} & $\mathrm{Cu}-14 \mathrm{Al}-3 \mathrm{Ni}-0.1 \mathrm{Cr}-0.1 \mathrm{~B}$ & 700 & $10^{-4}$ & 0.4 & 170 & $\gamma+\beta$ 二相混合 $(\sim 6 \mu)$ & 無 \\
\hline & $\mathrm{ZrO}_{2}-20 \mathrm{Al}_{2} \mathrm{O}_{3}-3 \mathrm{molY}_{2} \mathrm{O}_{3}$ & $1250 \sim 1500$ & $10^{-7} \sim 10^{-3}$ & 0.5 & $\sim 200$ & 二相混合 $(\sim 0.5 \mu)$ & 無 \\
\hline 1988 & $\mathrm{Al}-4 \mathrm{Cu}-2 \mathrm{Mg}-1 \mathrm{C}-0.80$ & $425 \sim 475$ & $10^{-4} \sim 10^{+2}$ & 0.3 & $\sim 500$ & 微細再結晶粒 $(\sim 0.5 \mu)$ & - \\
\hline$*$ & $\mathrm{Al}-10 \mathrm{Mg}-0.1 \mathrm{Zr}$ & 300 & $10^{-4} \sim 10^{-2}$ & 0.5 & $\sim 500$ & 亜結晶粒 $(1 \sim 2 \mu)$ & 有 \\
\hline$*$ & $\mathrm{Fe}-25 \mathrm{Cr}-7 \mathrm{Ni}-3 \mathrm{Mo}$ & 1000 & $10^{-3} \sim 10^{-1}$ & - & $>1300$ & 二相混合 (业結晶 $\alpha+$ 微細 $\gamma$ ) & 有 \\
\hline
\end{tabular}

相合金の超塑性が等量あるいはそれに近い相比におい て良好な特性を示すのは, 超塑性の主変形機構である 粒界すべりのすべり量が異相界面では同相界面より大 きい事に起因する。図 2 は, 代表的な超塑性ミク口組 織の実例である，図 2 (a) は, 実用アルミニウム青銅 $(\mathrm{Cu}-10 \mathrm{Al}-5 \mathrm{Ni}-5 \mathrm{Fe}-2 \mathrm{Mn})$ 合金の $(\alpha+x)$ 二相等量混 合組織で，その平均粒径は両相とも $2 \mu \mathrm{m}$ 程度である. 図 2 (b) は, 実用 $7475(\mathrm{Al}-6 \mathrm{Zn}-2 \mathrm{Mg}-2 \mathrm{Cu}-0.2 \mathrm{Cr})$ ア ルミニウム合金の $15 \mu \mathrm{m}$ の微細均一な静的再結晶粒 から成る単相組織である. 上述してきた超塑性ミクロ 組織は, 多くの超塑性材料のミクロ組織から類推され た代表例である。しかし, 逆に新しい超塑性材料開発 の指針と成り得るわけで, 実際, 新しい超塑性材料開 発に大きく寄与したことは事実である。

超塑性変形の機構解明は, その巨大伸び值故, 昔か ら非常に関心を集めた。当然ながら超塑性变形機構モ デルは, 超塑性ミクロ組織の特徴をうまく説明できる よう十分考慮されて確立された。. 結晶粒の形状は超塑 性変形中変動しないことが大きな特徴であるから, 大 きな伸び值を得るためには結晶粒の隣接粒相互の相対 的位置が変化しなければならない.こうした事が可能 であるためには, 粒内変形 (準均質変形) ではなく,
粒界の変形すなわち粒界すべり（非均質変形）が起ら なければならない. 実際, マーカー法による表面観察 や走査型電子顕微鏡による直接観察などで結晶粒の粒 界すべりが確認され, 超塑性変形の全ひずみ量の $60 \%$ から $90 \%$ 近くを粒界すべりによる変形が占めて いる. 代表的な超塑性ミク口組織の帰納的考察から推 測される超塑性変形の主機構は, 基本的に粒界すべり であることは疑う余地はないだろう。

\section{3 超塑性ミクロ組織に対する認識の変化}

代表的な超塑性材料のミクロ組織の類推から得られ た超塑性ミクロ組織の特徴は, ミクロンオーダーの微 細均一組織と, 高温変形間中のミクロ組織の安定性で ある. この事実に立脚して超塑性の正当な歴史が展開 され, この特徵が超塑性発現条件の伝統的見解となっ ている.しかしながら，表I中に*印で示したように， 必ずしもミクロンオーダーの微細均一組織で無くても, かなり良好な超塑性特性を示す異端例が各時代に存在 したこともまた事実である。こうした従来の一般的な 超塑性ミク口組織の分類に当てはまらない異端例の歴 史的推移を整理した結果が図 3 である. 図 3 は異端例 の報告が各年代の超塑性関連の全報告にたいして占め る割合の変化を示している，時代とともに異端例の占 

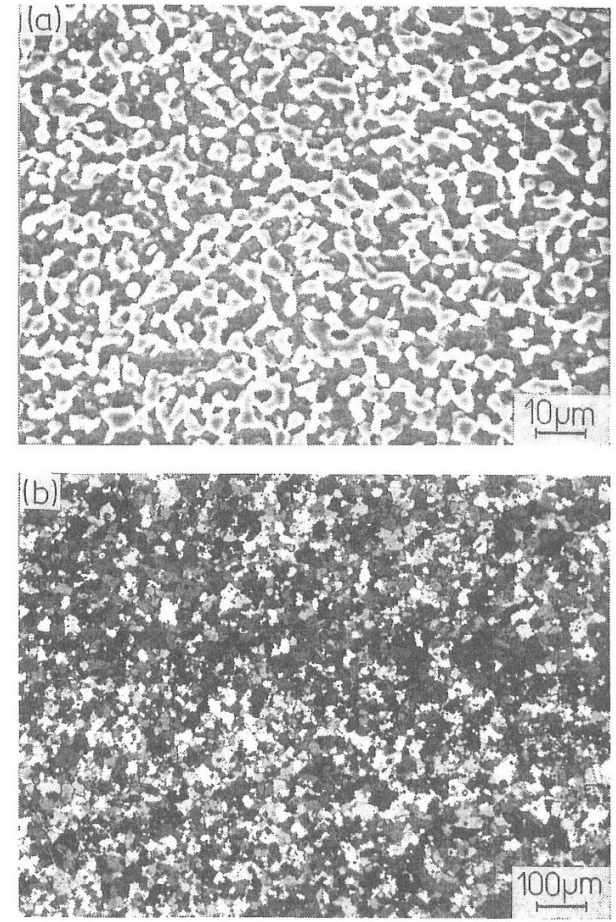

(a) 実用 C6301 アルミニウム青銅 (Cu-10Al-5Ni-5Fe-2Mn) 合金の $(\alpha+x)$ 二相等量の複相組織，黒地が $\alpha$-母相，白 W粒子が $x$ 相

(b) 寨用 7475 アルミニウム $(\mathrm{Al}-6 \mathrm{Zn}-2 \mathrm{Mg}-2 \mathrm{Cu}-0.2 \mathrm{Cr}$ ) 合 金の微細均一再結晶粒から成る単相組織

図 2 代表的な超塑性材料のミク口組織の実例

める割合が増加している事は明らかである。この異端 例の増加は新しい加工熱処理法による超塑性実用合金 の製造方法の発展と歩を合わせている. 新しい加工熟 処理法の発展とともに, 従来の一般的な超塑性ミクロ 組織の分類に当てはまらない組織を持つ材料からも超 塑性が生まれてきたわけである。超塑性ミクロ組織に 対する認識において，このような変化が生じてきた事 は確かである。

表 I 中に*印を付した材料の大きな特徵は, 変形初 期に扔いて，そのミクロ組織が大きく変化することで ある. 当然，このミクロ組織の変化はひずみ誘起粒成 長以外の恋化を意味する。 この恋形途中で合金のミク ロ組織が大きく変化する実用アルミニウム合金と実用

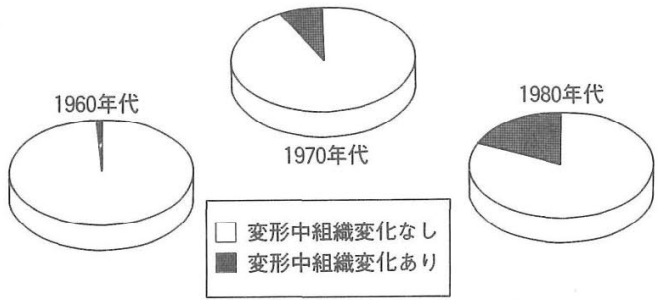

図 3 従来の一般的な超塑性ミク口組織の分類に当 てはまらない異端例の歴史的推移
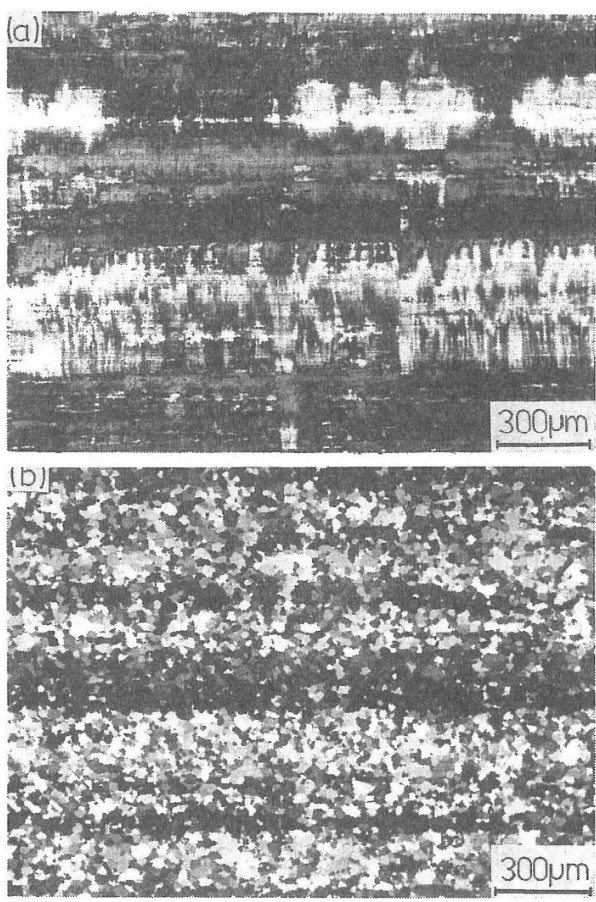

図 4 実用 8090 アルミニウム $(\mathrm{Al}-2.5 \mathrm{Li}-1 \mathrm{Cu}-1 \mathrm{Mg}$ $-0.2 \mathrm{Zr}$ ）合金の超塑性变形前後に扝ける代表的 なミク口組織変化。变形条件 : $520^{\circ} \mathrm{C}, 1 \times 10^{-3}$ / $\mathrm{s}$; (a) 変形開始前, (b) 変形途中 $(\varepsilon=0.8)$

ステンレス鋼の例を図 4 抒よび図 5 に各々示す。両図 は，これらの合金の変形開始直前と変形途中 $(\varepsilon \doteqdot 1)$ での代表的ミクロ組織を示している。図 4 では，变形 により加工組織の残留した未再結晶組織が微細均一再 結晶粒組織に変化し，また，図 5 では粗大な $(\alpha+\gamma)$ 二相混合組織か微細均一な $(\alpha+\gamma)$ 二相組織に变化し ている。従来の超塑性ミクロ組織は，図 6 に示すよう に，変形量に伴い単に粒成長するのみで相の種類やそ の結晶粒の形状などは大きく変化しない。しかし, 図 4 扔よび図 5 に示した両合金では，変形途中で合金の 初期ミク口組織が大きく変化する。

今までに報告された変形途中で大きくミクロ組織が 変化する合金の組織変化の特徴を分類し，その变化を 模式的に示した結果が図 7 である.

(1)は，粗大再結晶粒が変形により亜結晶粒に変化 するタイプである。このタイプの代表的な例は，1972 年に Griffiths とHammond により報告された $\beta$ チ夕 ン合金での観察例である。歷史的にみてもこの報告例 が粗大粒超塑性の第一号であろう. $500 \mu \mathrm{m}$ 以上の粗 大な再結晶粒組織が変形により熟的に安定した微細な 亜結晶粒に変化するもので，かれらはこの微細亜結晶 粒が超塑性発現の原因であると考えている。同様な組 織変化がその後, Hammondや Hamiltonにより $\beta$ 于 タン合金で多く報告されている. Hamilton らは，こ 


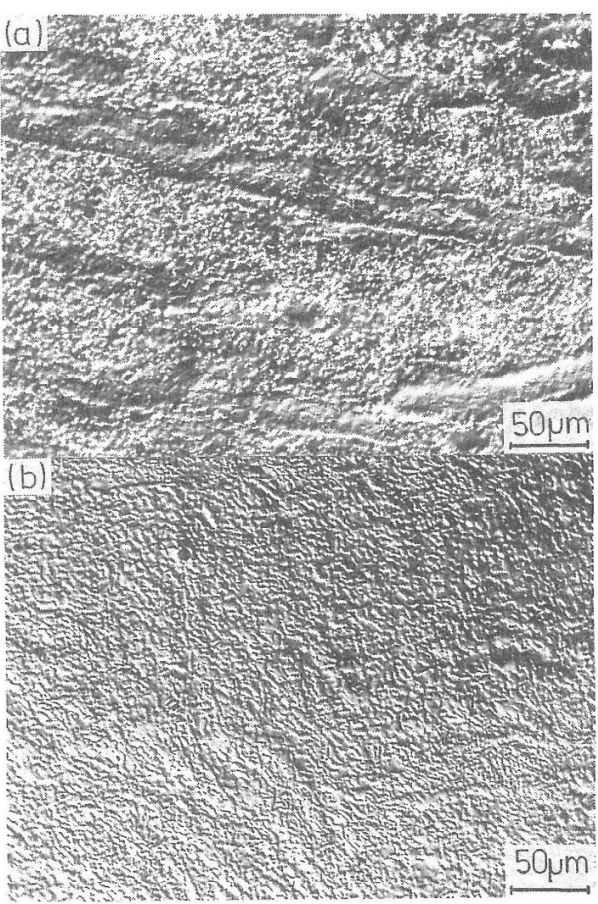

図 5 実用 SUS329J1 ステンレス鋼 $(\mathrm{Fe}-25 \mathrm{Cr}$ 6Ni-3Mo）の超塑性変形前後における代表的な ミク口組織变化. 变形条件 : $950^{\circ} \mathrm{C}, 1 \times 10^{-3} / \mathrm{s}$ (a) 変形開始前, (b) 変形途中 $(\varepsilon=0.9)$

（飴山惠氏提供）

のタイプの超塑性は,この微細な亜結晶粒に起因して いるのではなく， $\beta$ 相が大きな拡散速度を有している 事が本質的原因であると報告している。この変形間中 に形成される严結晶粒がさらに動的再結晶するかどう かは原論文では報告されていない。しかし最近, Hammond らは高速ねじり試験により得られた大ひず み域において，変形中に形成された雨結奛粒がさらに 動的再結晶する証拠写真を得ている。

（2）は，粗大な伸長あるいは層状組織が，変形によ りせん断されて微細均一組織に変化するタイプである。 元々，このタイプは，共晶，共析合金を含めた複相合 金において観察されることが多い.

(3) は, 微細互結晶粒から成る単相の粗大結晶粒が, 変形により微細均一再結晶粒に変化する夕イプである。 このタイプの代表例は，単相あるいはそれに近いアル ミニウム合金においてよく観察される。これらの合金 のミク口組織の特徵は変形開始直前の未再結晶加工組 織にある。この未再結晶加工組織は，ピンニング粒子 $\left(\mathrm{Al}_{3} \mathrm{Zr}\right)$ の微細均一分散により静的再結晶が顕著に抑 制される事で得られ，変形途中でこの未再結晶加工組 織から微細等軸再結晶粒に動的に組織変化する。この タイプの最も有名な実例は，英国にて開発された 2004 (Al-6Cu-0.4Zr ; 商標名 Supral) 合金で, 現在

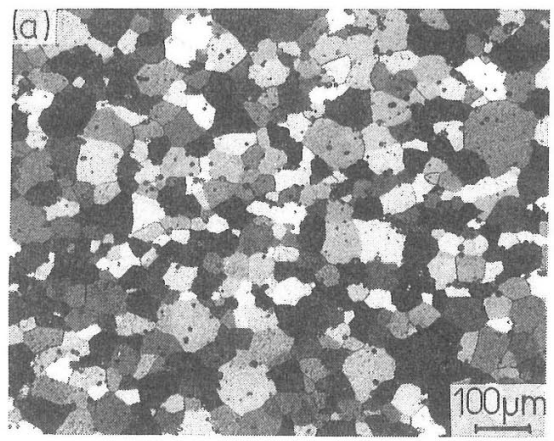

(a) 変形開始前

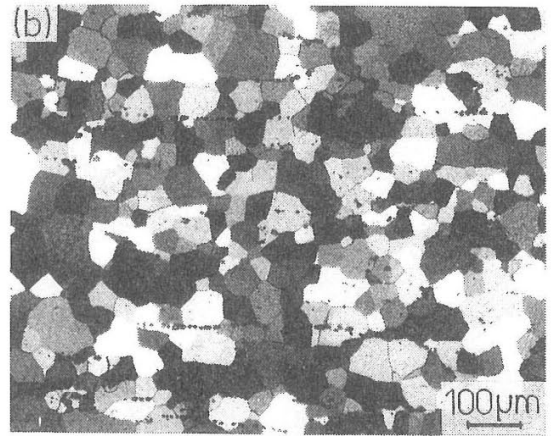

(b) $\varepsilon=1$

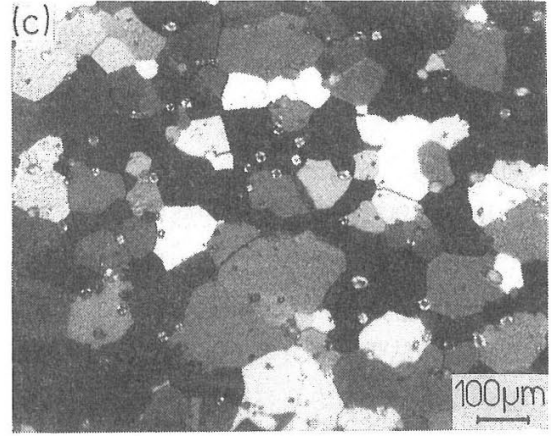

(c) $\varepsilon=2$

図 6 従来の実用超塑性 7475 アルミニウム合金 $(\mathrm{Al}$ $-6 \mathrm{Zn}-2 \mathrm{Mg}-2 \mathrm{Cu}-0.2 \mathrm{Cr}$ ) の超塑性変形中の組 織変化.ひずみ誘起粒成長のみが生じており, 図 4 のような大きなミク口組織の変化はない

Superform Metals 社が超塑性成形用材料として実用 化している。このタイプの超塑性が，次期航空機用ア ルミニウム合金として開発中の Al-Li 合金にて観察 され，現在非常に注目されている。

（4）は, 複相合金の動的な相分離（動的析出）ある いは相変態により，粗大組織から微細均一組織に変化 するタイプである。この粗大組織の下部構造は, 通常 亜結晶粒組織加成り，変形中に動的再結晶する場合 が多い。また，変形開始以前に既に粗大相が存在して いる場合には，(2) で示した組織変化が同時に起こり， 均一微細化する。二相合金の相分離あるいは相変態と， 加工とを組み合わせた組織微細化処理は，従来からの 
(1)

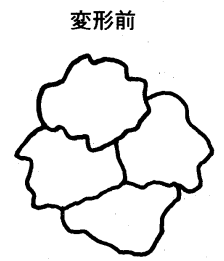

粗大再結晶粒

(2)

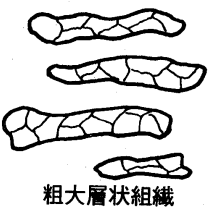

(3)

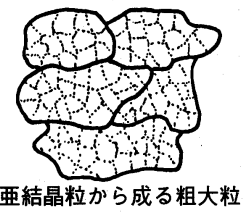

(4)

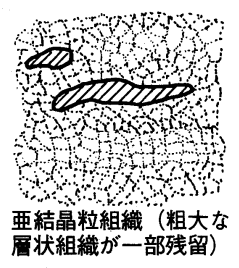

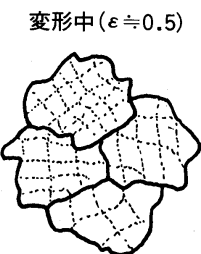

亜結晶粒の形成
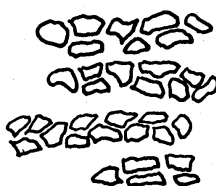

粗大粒の分断.
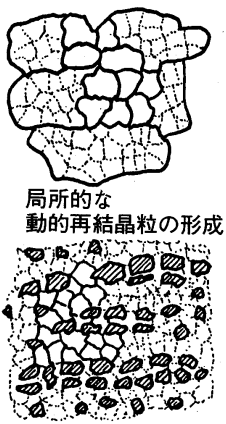

動的析出と動的再結晶の

競合（粗大粒の分断）

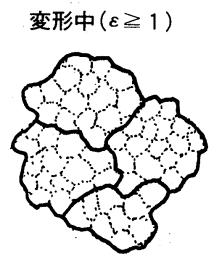

亜結晶粒の安定化

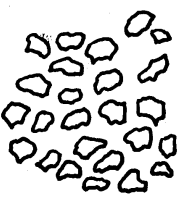

微細均一分散
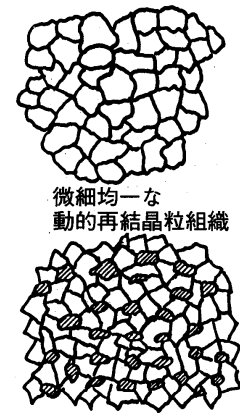

図 7 変形途中におけるミクロ組織変化の特徵の模式図

加工熱処理法の一般例である. しかし，この(4) タイ プでは，相分離や相変態が高温で残留している亜結晶 粒界上で優先的に起きたり，あるいは高温変形時のひ ずみ（格子欠陥）誘起により促進される事が大きな特 徵である。この結果，相分離や相変態の発生頻度が増 加し, 静的な場合よりさらに微細均一な組織が得られ, かつ早期に二相安定組織に到達する。 $(\alpha+\beta)$ チタン 合金, $(\alpha+x)$ アルミニウム青鉰, $(\alpha+\gamma)$ 二相ステンレ ス鋼の超塑性に，このタイプのよい例を見ることが出 来る.

変形開始初期にそのミクロ組織が大きく変化する超 塑性材料では，この特徵に起因して従来の代表的な超 塑性材料とは異なる超塑性挙動を示す。この材料の超 塑性の代表的な利点は, 静的再結晶させた材料と比較 して超塑性が発現する変形速度がかなり大きいことと, 空洞の発生率が顕著に少ないことである。これらの利 点は, 超塑性の工業的利用の観点から非常に望ましい ことである。

\section{4 超塑性変形途中でのミクロ組織変化}

変形途中で初期ミクロ組織が大きく変化する超塑性 材料の内で，特に印象的，かつ衝撃的な超塑性合金は, 前述した 2004 合金に代表される動的再結晶型超塑性 アルミニウム合金と $(\alpha+\gamma)$ 二相ステンレス鋼であろ
う．両合金の変形中の組織变化の基本的特徵は，図 7 (3) (4) に示した模式図の通りである. しかし，今なお この変形途中の組織変化の機構は明確とは言えない. ここでは,この変形途中の組織変化に関する最近の研 究のいくつかを紹介する.

\section{$4 \cdot 1$ 動的再結晶型超塑性アルミニウム合金}

2004（supral）合金に代表される動的再結晶型超塑 性アルミニウム合金の研究は，表Ｉに見るように，歴 史的にはかなり古くから英国を中心に行なわれてきた. 我国では，ここ数年特に著しい進歩を見せている。こ の合金の特徵は, 超塑性変形開始直前の未再結晶加工 組織にある。この未再結晶加工組織が変形途中で動的 再結晶して均一微細組織に変化する. この未再結晶加 工組織は, 微視的には微細な亜結晶粒から構成されて いる. 変形に伴うこの亜結晶粒の動的変化を図 8 に示 す. 変形に伴い帚結晶粒の粒界傾角が連続的に増加し, つまり変形前の小傾角から大傾角に移行する事で再結 晶が起こる (図 8(a))。この傾角の変化に対応して, 亜結晶粒の粒径が大きくなり, 数 $\mu \mathrm{m}$ 以下の微細な動 的再結晶粒が得られる（図 8(b))。こうした変形中の 粒界傾角の増大は, 他のアルミニウム合金の動的再結 晶においてもよく観察される特徵である。

さて, こうした変形前の初期未再結晶加工組織は, 


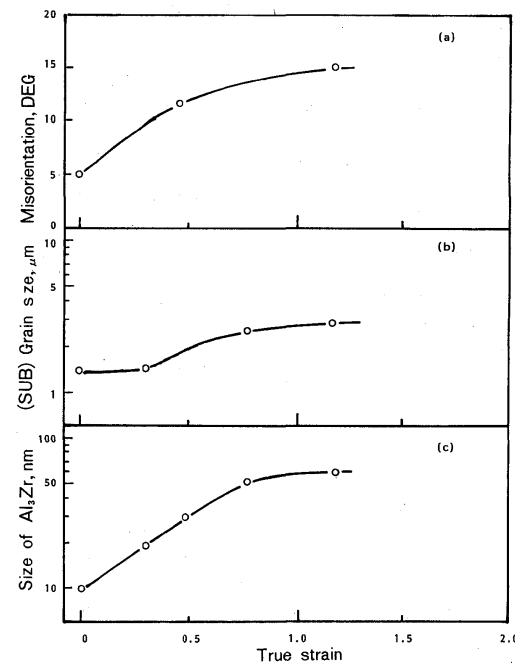

図 $8 \mathrm{Al}-6 \mathrm{Cu}-0.4 \mathrm{Zr}$ アルミニウム合金の変形に伴 うミクロ組織の動的変化, 変形条件; $420^{\circ} \mathrm{C}, 2$ $\times 10^{-2} / \mathrm{s}$

ピンニング粒子 $\left(\mathrm{Al}_{3} \mathrm{Zr}\right)$ の微細均一分散に起因した静 的再結晶の顕著な抑制によって得られる. 図 8 (c) に は, このピンニング粒子 $\left(\mathrm{Al}_{3} \mathrm{Zr}\right)$ の寸法変化を示して いるが，変形とともに粒子寸法の増加が認められる.

したがって，ここで観察される動的再結晶は，このピ ンニング粒子の寸法増加にともなう粒界移動阻止能力 の低下に起因して生じたものと推測される. それ故, この場合の動的再結晶は一度だけ起こると考えられ， 変形中繰り返し起こる動的再結晶とは異なる. Nes は 最近，このモデルの他に, $\mathrm{Al}_{3} \mathrm{Zr}$ 粒子の変形中の再 固溶を観察し, この再固溶による粒界移動阻止能力の 低下が，動的再結晶を導くと言うモデルを提案してい 告.

\section{$4 \cdot 2(\alpha+\gamma)$ 二相ステンレス鋼}

$(\alpha+\gamma)$ 二相ステンレス鋼は, 微細な二相等量組織 (40 - 50\% $\gamma$ 体積率) で超塑性を示す事は従来よりよ

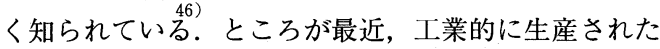
$(\alpha+\gamma)$ 二相ステンレス鋼 (SUS329) が，2000\% 以上 の大きな伸び值を $10^{-3} \mathrm{~s}^{-1}$ の比較的速い変形速度にお いて示す事，そしてこの合金のミクロ組織が超塑性変 形途中で大きく変化する事が報告された ${ }^{41), 47), 48)}$. この 超塑性 $(\alpha+\gamma)$ 二相ステンレス鋼の初期ミクロ組織は 非常に複雑で, 当然ながらその変形中の組織変化も単 純でない. 以下, 超塑性変形前後のミクロ組織の特徵 を整理して概説するが，ここではさらに簡便のため $\sigma$ 相の析出を伴わない条件下での組織变化のみについて 取り扱う。

$\sigma$ 相が析出しない条件での変形前のミクロ組織は二 種類ある. すなわち, $\alpha$ 相単相組織と，粗大 $\gamma$ 相と $\alpha$ 相の $(\alpha+\gamma)$ 二相組織である. $\alpha$ 単相組織を変形前の
組織とした場合には，基本的には，図 7 の(4) タイプ の変化が起る. 変形前の $\alpha$ 相は微細均一な亜結晶粒 から成る. 変形とともにこの亜結晶の粒界上に動的析 出した $\gamma$ 相が粗大化し，同時に動的再結晶して亜結 晶粒の傾角が大きくなり，最終的には $(\alpha+\gamma)$ 均一微 細二相混合組織が形成される. 後述する変形前の組織 を $(\alpha+\gamma)$ 二相組織とした場合の $\alpha$ 相にて生じる組織 変化と基本的には同一である。しかし， $\gamma$ 相が亜結晶 粒界上に動的析出するのでその析出する平均間隔が狭 くなり，最終的に得られる $(\alpha+\gamma)$ 二相混合組織は非 常に微細な組織になる．この微細組織が良好な超塑性 を発現させる大きな因子である.

$(\alpha+\gamma)$ 二相組織を変形前の組織とした場合, 変形 途中では粗大 $\gamma$ 相の分断と消滅による微細化と, $\alpha$ 相中の微小 $\gamma$ 相の粗大化，および $\alpha$ 相の動的再結晶 による微細化とが競合して起こり，最終的には $(\alpha$ $+\gamma)$ 二相微細均一組織 $(2 \sim 3 \mu \mathrm{m})$ が形成される.

$(\alpha+\gamma)$ 二相ステンレス鋼の変形中の大きな組織変 化に対する報告のすべては，現象論的には一致した見 解を取っている. しかし， $\alpha$ 相の動的再結晶による微 細化機構を含めた超塑性出現機構に関しては, 現在二 つの異なる主張がある，そのひとつは，硬い第二相に よる軟い $\alpha$ 相の局所的かつ間欠的な加工硬化と加工 軟化（変形中に何度も反復繰り返して起こる動的再結 晶）の微妙な平衡状態により超塑性が発現すると主張 するモデルである。この動的再結晶による新しい超塑 性機構モデルは，超塑性流動の平衡状態を変形と動的 再結晶による硬化一軟化の釣り合い状態の反復として 捉えており，理論的モデルとしては非常に興味深いも のである. かって, Baileyによって提示されたク リープ現象の硬化一軟化釣合モデルをを超塑性発現条件 に導入した最初の衝撃的なモデルと考えられる.この $\alpha$ 相が変形により繰り返し動的再結晶するモデルでは 従来の超塑性変形機構の粒界すべりモデルを完全に否 定している.

今ひとつのモデルは， $\alpha$ 相が微細な亜結晶粒から成 り,この亜結晶粒が硬い $\gamma$ 相周辺でのひずみ集中で 核生成サイトとなり，局所的な不連続再結晶によって 大傾角粒になるというもので, $\alpha$ 相の一回切りの動的 再結晶後では $(\alpha+\gamma)$ 二相混合組織の粒界すべりを基 本とした超塑性変形が生じると考えている.

いずれにせよ， $(\alpha+\gamma)$ 二相ステンレス鋼の超塑性 変形中の組織変化は，その機構の解明を含めて今後の 課題であろう。しかし，ここでは少なくとも，変形中 大きな組織変化を起こす $(\alpha+\gamma)$ 二相ステンレス鋼が, 良好な超塑性を示すことだけは明確に出来たと思う。

5 超塑性の構成方程式に対する認識の変化 超塑性材料に歴史的な推移があったように，超塑性 
(1) $\sigma=\mathbf{k} \dot{\varepsilon}^{\mathrm{m}}$

(2) $\sigma=\mathbf{k}(\mathrm{d})^{\mathrm{p}} \dot{\varepsilon}^{\mathrm{m}}\left\{\mathrm{D}_{0} \exp (-\mathrm{Q} / \mathrm{RT})^{)^{-1}}\right.$

$\mathrm{K}$; 定数, $\mathrm{m} ;$ ひずみ速度感受性指数

$\mathrm{d}$; 結晶粒径, $\mathrm{p}$; 結晶粒径指数

$\mathrm{D}_{0} \exp (-\mathrm{Q} / \mathrm{RT})$; 拡散係数, $\mathrm{T}$; 絶対温度

(3) $\sigma=\sigma_{0}+\mathrm{H} \varepsilon$

$\mathrm{Q}$; 活性化エネルギー, $\mathbf{R}$; ガス定数

$\log \sigma_{0}=\mathbf{A}_{0}+\mathbf{A}_{1}(\log \dot{\varepsilon})+\mathbf{A}_{2}(\log \dot{\varepsilon})^{2}$

$+\mathrm{A}_{3}(\log \dot{\varepsilon})^{3}+\mathrm{A}_{4}(\log \dot{\varepsilon})^{4}$

$\mathrm{H}$; 硬化係数, $\mathrm{A} 0, \mathrm{~A} 1, \mathrm{~A} 2, \mathrm{~A} 3, \mathrm{~A} 4$; 定数

(4) $\sigma=\mathbf{k} \varepsilon^{\mathrm{n}} \dot{\varepsilon}^{\dot{m}}$

$\mathrm{k} ;$ 定数, $\mathrm{n} ;$ ひずみ硬化指数

$\mathrm{m}$; ひずみ速度感受性指数

図 9 超塑性構成方程式の歴史的流れ

構成方程式もまた長い歴史を有する．図 9 は超塑性構 成方程式の歴史的流れを，また図 10 は代表的な真ひ ずみ一真応力曲線の推移を示す．構成方程式の原点は, 超塑性研究の巨人, Backofen が 1960 年代に提案した

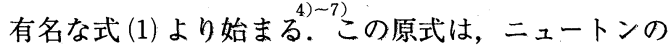
完全粘性流動方程式である. 図 10 (a) に示すように, 超塑性の定常流動応力状態を硬化（応力の増加）と軟 化 (応力の低下) の動的平衡状態として捉えている. それ故，応力のひずみ依存性は考慮しなくても良い． この概念は超塑性変形中の組織変化が起らないという 金属組織学的根拠からも支持された。この式は高温変 形におけるDorn 型の半経験的構成方程式に組み込ま れ, Dorn一派を中心に実験的に発展して, 最近, Mukherjeeによって式(2)ように総括された。.

1970 年代, Rockwell International の研究グループ によって，超塑性ブロー成形用の加圧プロセス制御法 の確立を目的とした定ひずみ速度引張試験による超塑 性流動応力の新しい評価法が確立されだ. その主な理 由は, 従来の定クロスヘッド速度引張試験では, 超塑 性伸び值の増加に伴い試験片平行部のひずみ速度が低 下し，変形中の組織変化に起因した流動応力の正しい 変化を捉えることが出来ないためである．

この定ひずみ速度試験により得られた真ひずみ一真 応力曲線の代表例を図 10 (b) (c) に示す. (b) は伸び値 とともに流動応力が増加し, 加工硬化のみが顕著に観 察される例である．超塑性状態（大きな $\mathrm{m}$ 值を示す 変形条件）においては，この加工硬化による流動応力 の増加はひずみにたいしてほほ直線的に増加する。こ
のような変化を示す材料にたいして，Ghosh らは， 式(2)を拡張した式(3)を提案した. ここで観察される 加工硬化は単に超塑性変形中の結晶粒成長のみに因る ものである.このタイプの真ひずみ一真応力曲線を示 す合金は, ミクロンオーダーの微細均一結晶粒を持ち, 変形中に大きく組織変化しない従来のいわゆる代表的 な超塑性材料である.このような超塑性材料の変形量 $\varepsilon$ に伴う変形中の結晶粒径 $d$ は, $d=d_{\mathrm{i}}+\mathrm{c} \varepsilon\left(d_{\mathrm{i}}\right.$; 初 期粒径, c ; 材料定数) で表わされる. この式と式 (2) により, 次のような関係式, $\sigma=\mathrm{K} \dot{\varepsilon}^{\mathrm{m}}\left(d_{1}+\mathrm{c} \varepsilon\right)^{\mathrm{p}}$ が得ら れる. この式より, 定数 $\mathrm{m}, \mathrm{p}$ がひずみ $\varepsilon に$ に依存せず, ひずみ速度が常に一定であれば, 応力がひずみ量に伴 い増加することは自明である.

一方, (c) は, 伸び值の増加に伴い流動応力が増加 する事は (b) と同様であるが，ある変形量以降は流動 応力が飽和あるいは低下している例である。このタイ プの真ひずみ一真応力曲線は, 変形初期では加工硬化 が，そして変形途中から加工軟化が連続的に起る事を 意味している．それ故，変形中に生じる加工硬化と加 工軟化は当然ひずみ依存性を有している．したがって， 式 (1) (3)を用いることは当然出来ないので, 基本的 には式 (4)を念頭において新しい構成方程式を考慮し ていかなければならない，実は，変形初期にそのミク 口組織が大きく変化する合金こそが，このタイプの真 ひずみ一真応力曲線を示すのである. (c)のタイプの 真ひずみ一真応力曲線が，変形中ひずみ速度が変化し ない定ひずみ速度引張試験で得られたものであるから， ここで観察された流動応力の変動は, 超塑性変形中に 生じるミク口組織の大きな変化に対応しているはずで ある．以下では，このタイプの材料が大きな超塑性伸 び值を示す理由について, 変形の塑性不安定性の観点 より概説する。

\section{6 変形の塑性不安定性 (Plastic Instabil-} ity)により再確認される超塑性材料

超塑性材料のミク口組織に対する認識の変化と超塑 性流動応力の構成式の変化を歴史的流れに沿って眺め た．その結果，超塑性ミク口組織に対する従来の認識 の範ちゅうからはみ出した超塑性材料の一群が正史の 裏に存在することを明確にする事が出来た．この一群 の超塑性材料に共通した組織的特徴は, 高温変形途中 (a)
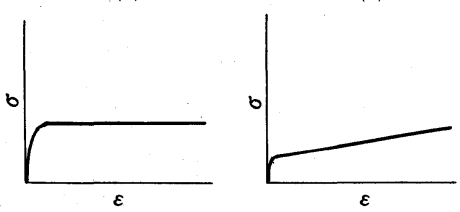

図10 超塑性材料の代表的な真ひずみ-真応力曲線の歴史的推移

(c)

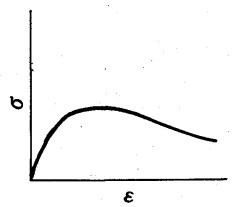
移 
でその初期ミクロ組織が大きく変化する事である。一 般に受け入れられている超塑性組織の特徴は, ミクロ ンオーダーの微細均一組織と, 高温変形中の組織安定 性である（事実，筆者も学生時代このように教えられ た)。この超塑性ミク口組織の特徴を基本にして超塑 性の構成式が提案され，また超塑性の基本的特徵であ る巨大伸び值と低流動応力のひずみ速度依存性をうま く説明してきた。まさにこの研究の積み重ねが超塑性 の輝かしい歷史であった。こうした由緒ある超塑性材 料の正史を否定する事なく，また異端的超塑性材料の 特徴をも止揚した新しい体系を築き上げることはそう 容易ではない.この回答は超塑性変形の塑性安定性を どのように捉え直すかという問題と同等である.

従来の超塑性材料と異端的超塑性材料の大きな違い は，超塑性変形中の組織変化の有無である．しかし， 従来の超塑性材料に扔けるひずみ誘起粒成長をもこの 変形中の組織変化とすれば，厳密にはやはり組織変化 が起こっているわけである，実際，定ひずみ速度試験 では，ひずみ誘起粒成長に起因した流動応力の増加が 観察される，そこで，以下では最初から超塑性変形中 に組織変化が本質的に生じると仮定し，ひずみ速度が 一定の条件下で得られた真ひずみ一真応力曲線を基に 変形の安定性条件より両超塑性材料（従来の超塑性材 料と異端的超塑性材料）の塑性安定性を検討し, 両超 塑性材料の超塑性特性の統合を試みる。

ここでは，Hartの変形安定性条件を採用する。 の条件は, 試験片の断面積の減少速度がその断面の減 少とともに小さくなることで, 次式で表わされる.

$$
\delta \log \dot{\mathrm{A}} / \delta \log \mathrm{A} \geqq 0
$$

また，具体的な構成方程式を仮定することが出来ない から，以下のように考える．まず，任意の変形径路に おいて，任意の時間における増分 $d \sigma, d \varepsilon, d \dot{\varepsilon}$ の相 互関係を,

$$
d \log \sigma=\gamma d \varepsilon+\mathrm{m} d \log \dot{\varepsilon}
$$

とする.ここで,

$$
\begin{aligned}
& \mathrm{m}=(\partial \log \sigma / \partial \log \dot{\varepsilon}), \\
& \gamma=((1 / \sigma)(\partial \sigma / \partial \varepsilon)) \text { である. }
\end{aligned}
$$

荷重 $\mathrm{F}=\sigma \mathrm{A}$ は, 試験片断面の任意の位置で常に一 定であるから， $\delta \mathrm{F}=\mathrm{A} \delta \sigma+\sigma \delta \mathrm{A}=0$ の関係が成立す る.これらより, 最終的に次式が得られる.

$$
0=(\delta \mathrm{A} / \mathrm{A})(1-\gamma-\mathrm{m})+\mathrm{m}(\delta \dot{\mathrm{A}} / \mathrm{A})
$$

それ故, 式 (6.1)は

$$
(\delta \log \dot{\mathrm{A}} / \delta \log \mathrm{A})=-(1-\gamma-\mathrm{m}) / \mathrm{m}
$$

と書き換えることが出来る. ここで,

$$
\mathrm{I}(\varepsilon)=(1-\gamma-\mathrm{m}) / \mathrm{m}
$$

を変形に伴う塑性不安定パラメータと定義する.

適切な構成方程式を仮定できないから，任意のひず み速度で定ひずみ速度試験を実際に行い，任意のひず

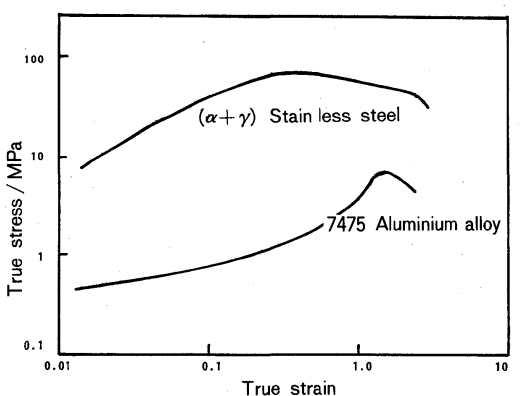

図11 定ひずみ速度試験にて得られた超塑性 7475 アルミニウム合金と $(\alpha+\gamma)$ 二相ステンレス鎆 の真ひずみ一真応力曲線の両対数プロット

み量での $\mathrm{m}$ および $\gamma$ を測定する。そして，式 (6.5) より $\mathrm{I}(\varepsilon)$ を計算する．ここで，Hart の変形安定性の 条件式 $(6.1)$ より， $\mathrm{I}(\varepsilon) \leqq 0$ を満足する $\mathrm{m}$ および $\gamma$ を 与えるひずみ速度域とひずみ量域で変形の安定性が少 なくとも保証され得るわけである。この条件を採用す れば，超塑性変形中の組織変化を包括した超塑性巨大 伸び值の出現理由を力学的に明確に説明することが出 来るはずである.

以下，実際の超塑性材料を用いて，超塑性状態での 変形の安定条件を検討してみよう。ここでは, $10 \mu \mathrm{m}$ の均一微細再結晶粒から成る超塑性 7475 アルミニウ 么合金を従来の超塑性材料の, また粗大 $\gamma$ 相と $\alpha$ 相 の不均一な二相混合組織から成る $(\alpha+\gamma)$ 二相ステン レス鋼を異端的超塑性材料の代表例として各々用いる。 両合金の定ひずみ速度試験下で得られた真ひずみ一真

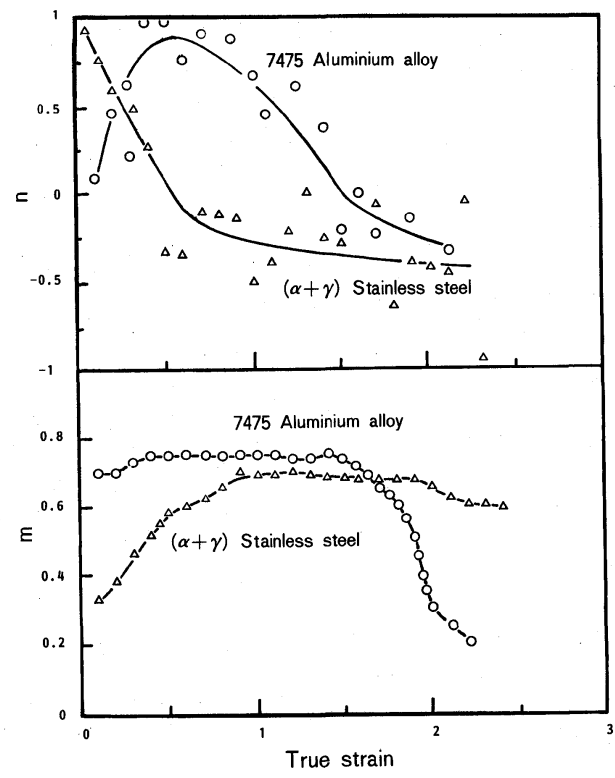

図12 超塑性 7475 アルミニウム合金と $(\alpha+\gamma)$ 二 相ステンレス鋼のひずみに伴う $\mathrm{m}$ 值と $\mathrm{n}$ 值の 変化 


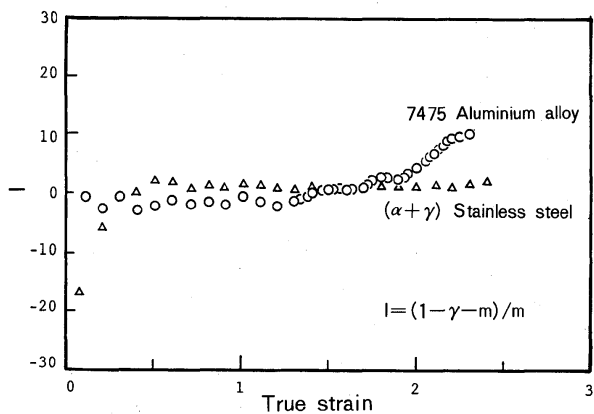

図13 超塑性 7475 アルミニウム合金と $(\alpha+\gamma)$ 二 相ステンレス鋼のひずみに伴う変形の塑性安定 性パラメータ $\mathbf{I}(\varepsilon)$ 值の変化

応力曲線を両対数で示したのが図 11 である. 超塑性 7475 アルミニウム合金は図 10 (b) タイプ，また $(\alpha$ $+\gamma)$ 二相ステンレス鋼は図 10 (c) タイプである. 加工 硬化係数 $\mathrm{n}$ 值（図 11 の曲線勾配）とひずみ速度急変 法より求めた $\mathrm{m}$ 值のひずみに伴う変化を図 12 に各々 示す．両合金の超塑性挙動の違いは明確である。これ らの $\mathrm{n}, \mathrm{m}$ 值より算出した $\mathrm{I}(\varepsilon)$ の変化を図 13 に示す。 両合金の $\mathrm{n}, \mathrm{m}$ 值はひずみ量に伴い共に異なる变化を 示したのに対し， $I(\varepsilon)$ 值は，共に負あるいはゼロに近 い值を示し，大きな変形量まで変形が安定であるとい う結果を示している．このように，変形中の組織変化 の違いによる $\mathrm{n}$ および $\mathrm{m}$ 值の変化を, Hart の変形の 安定条件で統一する事が可能で，かつ巨大超塑性伸び 值の出現理由がこの条件で保証され得る事が判る。今 後, 変形中の組織変化と $\mathrm{n}$ および $\mathrm{m}$ 值の変化の対応 性が明確になれば超塑性変形の本質的な構造解析が今 までとは異なった観点から行なわれるものと期待され る.

\section{7 おわりに}

本小文では，超塑性研究の歴史的流れを展望した. そして, 各時代の研究から遊離してきた超塑性ミクロ 組織に対する問題点を指摘し, 従来の超塑性材料の変 形中のミクロ組織変化とは異なる挙動を示す超塑性材 料の存在を明らかにした。つぎに，これらの超塑性材 料の変形中のミクロ組織変化に対する認識を総括し, 両材料の変形中の超塑性ミク口組織に対する認識の違 いが, 変形中の加工硬化と加工軟化の変動の違いに起 因する事を示した．また，両超塑性材料の巨大伸び值 の出現理由を変形の塑性安条件より明らかにした。

最後に，この小文をまとめるに際し，ご助言，ご指 導して頂いた大阪府立大学工学部伊藤太一郎教授に感 謝致します。また， $(\alpha+\gamma)$ 二相ステンレス鋼の組織 写真（図 4 ）を快く提供して頂いた立命館大学理工学 部飴山恵博士に謝意を表します。

\section{参 考 文 献}

1 ) G. D. Bengough, J. Inst. Met., 7, 123 (1912).

2 ) C. E. Pearson, ibid., 54, 111 (1934).

3 ) E. E. Underwood, J. Metals, 14, 914 (1962).

4 ) W. A. Backofen, I. R. Turner and D. H. Avery, Trans. of ASM, 57, 980 (1964)

5 ) D. H. Avery and W. A. Backofen, ibid., 58, 551 (1965).

6 ) D. L. Holt and W. A. Backofen, ibid., 59, 755 (1966).

7 ) S. W. Zehr and W. A. Backofen, ibid., 61, 300 (1968).

8 ) J. W. Moore, J. Tequesta and R. L. Athey, U. S. Patent 3. 519, 503 (1976)

9 ) D. Lee and W. A. Backofen, Trans. AIME, 239, 1034 (1976).

10) N. E. Paton and C. H. Hamilton, Met. Trans., A-10, 241 (1979).

11) B. M. Watts, M. J. Stowell, B. L. Baikie and D. G. E Owen, Met. Sci., 10, 198 (1976).

12) O. D. Sherby, B. Walser, C. M. Young and E. M. Cady, Scr. Metall., 9, 569 (1975).

13) O. A. Ruano, L. E. Eiselstein and O. D. Sherby, Metall Trans., A-13, 1785 (1982).

14) T. G. Nieh, C. A. Henshall and J. Wadsworth, Scr. Metall., 18, 1405 (1984)

15) T. G. Nieh, P. S. Gilman and J. Wadsworth, Scr. Metall., 19, 1375 (1985)

16) T. R. Bieler, T. G. Nieh, J. Wadsworth and A. K Mukherjee, Scr. Metall., 22, 81 (1988).

17) F. Wakai, S. Sakaguchi and Y. Matsuno, Advanced Ceramic Mate., 1, 259 (1986).

18) F. Wakai and H. Kato, Advanced Ceramic Mate., 2, 71 (1987).

19) Ed. by N. E. Paton and C. H. Hamilton, "Superplastic Forming of Structural Alloys" (1982) AIME, Warrendale, PA

20) Ed. by S. P. Agrawal, "Superplastic Forming" (1985) Metals Park, OH., ASM.

21) Ed. by R. Pearce and L. Kelly, Superplasticity in Aerospace-Aluminium, (1985) Ashford Press, Cranfield, England.

22) Ed. by B. Baudelet and M. Suery, "Superplasticity", Editions CNRS (1985) Grenoble, France.

23) Ed. by T. R. McNelley and H. Charles, "Superplasticity in Aerospace" (1988) AIME, Phoenix.

24) Ed. by M. Doyama and S. Somiya, MRS Intn. Meeting on Advanced Materials (1988) Tokyo, Japan.

25) Superplasticity and Superplastic Forming, Ed. by N. E Paton and C. H. Hamilton (1988) AIME, Seattle, WA.

26) 東 健司, 粉体工学会誌, 25, 528 (1988).

27）松木賢司，上埜安英，山田正夫，日本金属学会誌，38, 448 (1973).

28) A. E. Geckinli and C. R. Barrett, J. Mat. Sci., 11, 510 (1976). 
29) P. Griffiths and C. Hammond, Acta Met., 20, 935 (1972).

30) C. Hammond, private communication.

31) C. H. Hamilton, S. P. Agrawal, N. E. Paton, J. C. Chesnutt and E. D. Weisert, Rockwell International Science Centre Report J / 0442A / cb, undated.

32) G. Herriot, M. Suery and B. Baudelet, Scri. Met., 6, 657 (1972).

33) M. Suery and B. Baudelet, J. Mat. Sci., 8, 363 (1973).

34) G. Herriot, B. Baudelet and J. J. Jonas, Acta Met., 24, 687 (1976).

35) B. M. Watts, M. J. Stowell, B. L. Baikie and D. G. E. Owen, Met Sci., 10, 198 (1976).

36) K. J. Gardner and R. Grimes, ibid, 13, 216 (1979).

37）J. Wadsworth, 文献20）に同じ.

38） R. Grimes, 文献22）に同じ.

39）大隅 真, 高橋明男, 清水正治, 都筑隆之, 三菱重工技 報, 20-4，1（1983）.

40）東 健司, 未発表.

41）前原泰裕, 鉄と鋼, 73, 1722 (1987).
42) H. J. McQueen, E. Evangelista, J. Bowles and G. Crawford, Met. Sci., 18, 395 (1984).

43) K. Lintermanns and H. A. Kuhn, Aluminum alloy, their physical and mechanical properties, Ed. by E. A. Starke, Jr and T. H. Sandders, Jr, 1, 529 (1986).

44) M. R. Drusy and F. J. Humphreys, Acta Met., 34, 2259 (1986).

45）E. Nes, 文献22）に同じ.

46） N. Ridley, 文献19）に同じ.

47）牧 正志，第44回超塑性研究会資料（1988）.

48）飴山 恵, ibid..

49) R. W. Bailey, J. Inst. Met., 35, 27 (1926).

50) A. K. Mukherjee, J. E. Bird and J. E. Dorn, Trans. ASM, 62, 155 (1969).

51) H. W. Hayden, S. Floreen nd P. D. Goodell, Met. Trans., 3, 833 (1972).

52) B.P. Kashyap and A. K. Mukherjee, 文献22) に同じ.

53) A. K. Ghosh and C. H. Hamilton, Met. Trans., 13A, (1982).

54) E. W. Hart, Acta Met., 15, 351 (1967). 